\title{
Glauber Rocha e as imagens do sertão
}

\author{
Sylvia Nemer
}

\begin{abstract}
RESUMO
Este texto tem como objetivo discutir o problema da intertextualidade fílmica por meio da análise da apropriação da literatura de cordel em Deus e o diabo na terra do sol (1964) e em O dragão da maldade contra o santo guerreiro (1969), filmes de Glauber Rocha dedicados à representação do universo social e cultural sertanejo. A preocupação do cineasta com a forma de representaçăo, discutida em seus textos Estética da fome (1965) e Estética do sonho (1971), reflete-se, nos dois filmes estudados, no modo como estes lidam com o cordel. Recusando o tratamento da temática sertaneja pelo cinema político da época, o cineasta procurava retratar o sertão a partir de suas próprias tradições que passavam, contudo, por um processo de transformação visando a sua adaptação, em primeiro lugar, à narrativa cinematográfica e, em segundo, a uma perspectiva política inexistente nas manifestações da cultura popular.
\end{abstract}

Palavras-chave: cinema, história, cultura popular

\section{ABSTRACT}

This work aims to discuss the problem of film intertextuality by the analisys of literatura de cordel appropriation in the films of Glauber Rocha where the sertão, its social and cultural universe, is focused: Deus e o diabo na terra do sol (1964) and O dragão da maldade contra o santo guerreiro (1969). The question of form representation, discussed in his texts Estética da fome (1965) and Estética do sonho (1971), is reflected, in these two films, in the way the cordel is treated in each one. Refusing the approach of the sertão subject by the political cinema of the epoch, the cineaste looked for one kind of expression that incorporated the people's traditions of the region represented. These traditions, however, were not translated literally. They were, in fact, transformed to be adapted into the cinematographic language and also into the political perspective that originaly inexisted in them.

Key words: cinema, history, popular culture

- Sylvia Nemer é historiadora, doutora em Comunicação pela LFRJ, professora do IFCS-UFRJ e pesquisadora da Fundação Casa de Rui Barbosa. Atua nas áreas de Cinema, História e Teoria da Culsura nas quais tem antigos e capilulos de livros publicados no Brasil e no exterior. 


\section{Introdução}

Filmes de Glauber Rocha dedicados à representação do universo social e cultural sertanejo, Deus e o diabo na terra do sol (1964) e $O$ dragão da maldade contra o santo guerreiro (1969) se inspiram na literatura de cordel cujos versos articulam os respectivos enredos proporcionando modos de compreensão da temática nordestina distintos daqueles em voga no cinema político dos anos 60 . Considerando que houve uma significativa mudança na forma de ver o mundo e conceber a idéia de revolução no período que separa os dois filmes, procuraremos analisar o quadro de referências culturais que poderiam justificar, em cada um deles, as diferentes formas de apropriação da literatura de cordel: em um caso, lembrando as histórias que circulam nos folhetos, tal apropriação tem como base a idéia de narração; no outro, inspirada nos desafios repentistas, ela tem como referência a idéia de performance, de improviso, de que o ato de criação é simultâneo ao da realização. A concepção de tempo inerente a cada uma das duas modalidades da poesia popular sertaneja (o romance de cordel e o repente) ajuda a construir o sentido particular de cada uma das obras estudadas como se verificará a seguir.

\section{Deus e o diabo na terra do sol: a função da canção}

Deus e o diabo vincula-se ao cordel por meio do discurso utópico da salvação, presente nos folhetos de aventura e nos de profecia:

Manuel e Rosa viviam no sertão / trabalhando a terra com as próprias mão / Até que um dia, pelo sim, pelo não, / entrou na vida deles o Santo Sebastião / Trazia bondade nos olhos, / Jesus Cristo no coração.

Feito em uma época em que a idéia de revolução como necessidade histórica figurava na pauta ideológica de artistas e intelectuais de esquerda, o filme, através das canções que o acompanham, estabelece uma ponte entre o passado de injustiças e opressão e o futuro de esperança e liberdade.

Compostas por Sérgio Ricardo a partir de um poema escrito por Glauber Rocha, as canções narram em off a mesma história narrada no campo visual pelas imagens e ações dos personagens. Acompanhando a trajetória de Manuel em sua busca de salvação, as canções pontuam a história introduzindo o personagem, marcando os momentos de hesitação, de risco e de virada dos acontecimentos e indicando, no final, o caminho a seguir. Em sua ordem narrativa, Deus e o diabo repete a estrutura do cordel caracterizada por uma situação inicial de equilíbrio, sua quebra após um momento de crise e sua recuperação no final da história.

No folheto Juvenal e o dragão, de João Martins Athayde, temos um exemplo claro dessa construção: Juvenal era um rapaz humilde que vivia com 
a irmã na fazenda do pai. Com a morte deste, Juvenal resolve partir em busca de aventuras deixando a casa e os poucos bens com a irmã:

Ficou ela na choupana / cumprindo a sinal fatal / o seu nome era Sofia / o dele era Juvenal / que pensava em aventura / além do bem e do mal.

No caminho Juvenal encontra um homem que the vende três cachorros com poderes sobrenaturais. Mais adiante ele se depara com um cocheiro que lhe informa sobre uma princesa que está prestes a ser devorada por um dragão:

Juvenal ficou imóvel / vendo a triste narração, / perguntou logo ao cocheiro: / onde habita este dragão? / - numa furna dessa serra, / e apontou com a mão.

Ajudado por seus formidáveis cães, Juvenal luta contra o dragão e consegue salvar a princesa que se apaixona por ele. Juvenal, no entanto, resolve continuar sua viagem. A princesa, por sua vez, retorna ao castelo com o cocheiro que, dizendo ao rei ter sido o responsável pela libertação da sua filha, receberá como prêmio a permissão de casar-se com ela:

Apertou ele nos braços / cheio de contentamento, / dizendo: minha filha vive / pelo teu merecimento, / como não posso pagar-te / dou-te ela em casamento.

Desesperada a princesa chora pela volta de Juvenal, que parecendo ouvir seus apelos chega para salvá-la do cocheiro traidor. No final, Juvenal casa-se com a princesa tornando-se herdeiro do reino:

Casou-se com a linda princesa / o valente Juvenal / repercutiu a notícia / no palácio imperial/ rolou festa 15 dias / no palácio imperial.

Típico romance de aventuras, a história de Juvenal se fundamenta nos princípios da busca e da salvação que orientam também o percurso de Manuel do sertão até o mar. Porém, do folheto à tela de cinema, tais princípios passam por um processo de adaptação e transformação. No cordel, o sentido da busca não é a derrubada da ordem social, mas o seu restabelecimento após um período de perturbações. A luta, nesse caso, não constitui uma ameaça ao status quo mas, ao contrário, um instrumento de sua manutenção. $\mathrm{Na}$ tradição popular sertaneja, o mal, associado à ameaça à ordem, tem um sentido preciso. Seu combate depende da ação interventora do herói que salva a princesa das garras do malfeitor e, como prêmio por sua extraordinária coragem, casa-se com ela no final da história. 
Ao contrário da aventura de Juvenal, cujo esquema se repete em inúmeros folhetos, em Deus e o diabo o bem e o mal se confundem. Transcendendo o caráter e a ação dos personagens, o mal corresponde à exploração, à injustiça, ao abuso do poder, à alienação, ou seja, está relacionado a estrutura social. Isso torna o combate mais complexo pois a ação do herói não se limita à eliminação de um adversário. Seu papel é o de combater sempre mantendo vivo o espírito da busca. É assim que Deus e o diabo se filia à literatura de cordel e a toda uma tradição narrativa que, segundo Jerusa Pires Ferreira ${ }^{2}$, tem origem no romance ibérico de cavalaria. Através do 'mecanismo da busca contínua' imerso no imaginário sertanejo, Glauber Rocha propunha uma forma de pensar a revolução que rompia com o discurso tradicional de esquerda reproduzido pelo cinema militante.

Em suas críticas à arte de esquerda, o cineasta costumava denunciar a sua contaminação pelos esquemas da arte burguesa, fundada, segundo ele, sobre os princípios da razão conservadora. Essa argumentação, desenvolvida no texto Estética do sonho ${ }^{3}$, pressupunha uma preocupação com a forma do filme. 'A revolução', dizia ele, 'é uma estética'. Colocando em evidência questões relativas à estética cinematográfica, esse texto mostrava que não interessava a Glauber apenas o enredo, a história do filme, mas o modo como esta era narrada.

Através de Cego Júlio, que não apenas narra mas vivencia os acontecimentos narrados, Deus e o diabo estabelece uma ponte entre o 222 passado da narração e o presente das imagens mostradas:

Da morte em Monte Santo / sobrou Manuel Vaqueiro / por piedade de Antonio / matador de cangaceiro. / Mas a estória continua, / preste mais atenção: / andou Manuel e Rosa / nas vereda do sertão / até que um dia, / pelo sim, pelo não, / entrou na vida deles / Corisco, diabo de Lampião.

Sem recorrer ao tradicional flash-back, o filme de Glauber Rocha reporta-se ao passado, preservando o caráter ficcional da história narrada. Em seu estudo sobre Crepúsculo dos deuses, Paul Warren ${ }^{4}$ comenta sobre o efeito de realidade produzido no filme de Billy Wilder por meio da integração da voz de um homem morto, ao corpo desse mesmo homem que vive e explica em off os acontecimentos que levaram à sua morte.

Contrariando o sentido de utilização da voz off no cinema clássico, em Deus e o diabo a narração reforça a ambigüidade da história contada ajudando a preservar o inacabamento, característico, segundo Walter Benjamin ${ }^{5}$, da narração tradicional. Não interessa, nesse caso, $o$ estatuto de verdade do narrado mas o próprio ato de transmissão, a possibilidade do passado, transformado em memória, comunicar-se com o presente através da narração. Pois 'talvez haja crimes que não se devam esquecer, vítimas cujo sofrimento 
peça menos vingança do que narrativa. Só a vontade de não esquecer pode fazer com que esses crimes não voltem nunca mais' ${ }^{\prime}$. As palavras de Paul Ricouer ecoam na última canção do filme:

O sertão vai virar mar / e o mar virar sertão! / Tá contada a minha estória, / verdade, imaginação. / Espero que sinhô / tenha tirado uma lição: / que assim mal dividido / esse mundo anda errado, / que a terra é do Homem, / não é de Deus nem do Diabo.

\section{O dragão da maldade contra o santo guerreiro: a encenação do desafio}

Em 1969, Glauber Rocha volta-se mais uma vez para a temática sertaneja. Último trabalho lançado no Brasil antes de sua partida para o exterior, $O$ dragão da maldade contra o santo guerreiro traz novamente para a tela a figura de Antonio das Mortes que reaparece para cumprir a clássica tarefa de matador de cangaceiro. Muito mais do que uma continuação de Deus e o diabo, O dragão da maldade, feito em meio aos movimentos de contracultura, é um filme que problematiza o ato de representação estabelecendo um diálogo com outras instâncias cinematográficas, em particular com o western.

Gênero admirado por Glauber Rocha, o western, em $O$ dragão da maldade, recebe um tratamento paródico que sobressai na cena do desafio de Coirana e, em seguida, na do duelo entre este e Antonio das Mortes. Construídas segundo os principios do desafio repentista, tais cenas rompem com as regras do western onde o duelo, momento chave dos filmes do gênero, constitui o instante do suspense, da glorificação do herói e da vitória do bem sobre o mal. Negando essas convenções, $O$ dragão da maldade apresenta o duelo como um jogo, onde a luta, uma mistura de palavra declamada e movimento coreografado, desenvolve-se como uma performance, uma encenação teatral.

Meio de divulgação de histórias, o folheto de cordel, como a narrativa de Deus e o diabo, remete a algo ocorrido no passado que, por meio da voz do cantador, se transporta para o presente. $O$ desafio repentista, que informa a construção das cenas de duelo em $O$ dragão da maldade, é uma modalidade da poesia popular sertaneja cujas regras de composição diferem completamente das do folheto.

O desafio é uma forma de expressão oral na qual a criação é simultânea à transmissão e à recepção. Colocando em confronto dois poetas, essa poesia do instante é baseada no improviso, no domínio das regras e na capacidade de um dos poetas produzir o momento de surpresa que irá derrubar o oponente. Nesse duelo verbal, o público envolve-se, empolga-se e, sugerindo motes, interfere no espetáculo a favor de um ou outro concorrente. 
Disputa poética, o desafio normalmente se inicia com a apresentação dos poetas que falam de suas respectivas qualidades de cantador. Nas muitas versões que correm sobre a peleja entre o escravo Inácio da Catingueira e o branco Romano da Mãe-d'Água, parece que é Inácio quem procura Romano. Ele é quem aparece em Patos, pelos idos de 1874 e 1875, para enfrentar o valente cantador:

Romano: - Inácio, vieste a Patos / procurando quem te forre. / Volta pra trás meu negrinho / que aqui ninguém socorre: / E quem cai nas minhas unhas / apanha, deserta ou morre. Inácio: - "Seu" Romano, eu vim a Patos/pela fama do senhor, / que me disseram que era / mestre e rei de cantador / e que dentro de um salão / tem discursos de um doutor.

Depois do prólogo começam as provocações que se estendem até o momento em que um dos cantadores deixa o outro sem resposta, como aconteceu com Inácio diante do verso lançado por Romano:

Romano - Latona, Cibele, Réia, / Íris, Vulcano, Netuno, / Minerva, Diana, Juno, / Anfitrite, Androquéia, / Vênus, Climene, Almatéia, / Plutão, Mercúrio, Teseu, / Júpiter, Zoilo, Perseu, / Apolo, Ceres, Pandora; / Inácio desata agora / O nó que Romano deu!

Inácio: - "Seu" Romano, deste jeito / eu não posso acompanhá-lo; / se desse um nó em martelo / viria eu desatá-lo; / mas como foi em ciência / cante só que eu me calo. Romano: - Inácio, eu reconheço / que és bom martelador, / mas, agora que apanhastes, / dirás que tenho valor; / porque eu em cantoria / não temo nem a doutor.

Momento que antecede o duelo contra Antonio das Mortes, o desafio de Coirana se faz nos termos da tradição da poesia do repente. No meio da praça de Jardim das Piranhas, o cangaceiro, sob os olhares do professor e do delegado, prepara-se para iniciar o desafio que será lançado contra os poderosos do local. A fala de Coirana lembra as provocações feitas entre Romano e Inácio antes do desafio propriamente dito:

Eu vim aparecido. / Não tenho família nem nome. / Eu vim tangendo o vento / pra espantar os últimos dias da fome. / Eu trago comigo o povo desse sertão brasileiro / e boto de novo na testa um chapéu de cangaceiro. / Quero ver aparecer os homem dessa cidade, / o orgulho e a riqueza do Dragão da Maldade. / Hoje eu vou embora, / mas um dia eu vou voltar. / E nesse dia, sem piedade, / nenhum padre vai restar. / Porque a vingança tem duas cruz. / A cruz do ódio e a cruz do amor. / Três vez reze o padre-nosso, / Lampião nasceu, Senhor!

A cena se interrompe para mostrar o contexto em que se encontra Antonio das Mortes. Retirado do seu antigo ofício após a execução de 
Corisco, o matador é procurado pelo delegado Matos, uma espécie de aliado do coronel que controla a região. Retornando ao sertão para colocar um fim às desordens provocadas pelo bando de beatos e cangaceiros, Antonio das Mortes, um tanto hesitante quanto a sua decisão, acaba entrando em confronto com Coirana. Sob os olhares da população local, os adversários se posicionam no centro da praça.

Coirana: - Tenho mais de mil cobrança pra fazer, / mas se eu falar de todas a terra vai estremecer. / Quero só cobrar as preferida do testamento de Lampião. / Quem é homem vira mulher, quem é mulher pede perdão. / Prisioneiro vai ficar livre, / carcereiro vai pra cadeia. / Mulher dama casa na igreja / com véu de noiva na lua cheia. / Quero dinheiro pra minha miséria, / quero comida pro meu povo, / se não atenderem meu pedido / vou vortar aqui de novo.

Antonio: - Tu é verdade ou assombração? / Diga logo cabra da peste? / Eu de minha parte não acredito nessa roupa que tu veste.

Coirana: - Primeiro diga você seu nome, fantasiado. / Quem abre assim a boca fica logo condenado.

Antonio: - Pois aprepare seus ouvido e ouça. / Meu nome é Antonio das Mortes, / pra espanto da covardia / e desgraça da sua sorte. / Mas uma coisa eu digo: / no território brasileiro, / nem no Céu nem no Inferno, / tem lugar pra cangaceiro.

Após esse duelo verbal, os rivais, ao som dos cânticos e palmas do público que assiste ao confronto, se enfrentam em uma luta dançada que termina com o golpe de Antonio contra Coirana. O povo, diante do desfecho do conflito, continua a cantar contrariando as ordens do coronel que impotente não consegue interromper a manifestação dos aliados de Coirana.

Em $O$ dragão da maldade, a violência não diz respeito à representação da luta, mas à reação do povo que, em um ato de insubmissão, levanta sua voz contra seus opressores. Invertendo um dos princípios básicos da violência no cinema, onde o combate, em geral, se faz em função da exaltação do heroi, $O$ dragão da maldade desloca o foco de tensão da encenação do duelo para a sua recepção.

No western o combate é quase sempre acompanhado pelos olhares assustados dos observadores, cuja expressão intimidada faz aumentar a expectativa $\mathrm{cm}$ torno do desempenho dos dois rivais. Fazendo supor que se trata de um "duelo de gigantes", essa postura submissa da platéia prepara 0 clima para a glorificação do herói cuja vitória sobre o "poderoso" adversário justifica as honras recebidas no final.

Referindo-se à questão da recepção cinematográfica, Daniel Dayan ${ }^{7}$ comenta sobre o filme No tempo das diligências. Segundo Dayan, o clássico de John Ford não impõe, como as narrativas mais simples, uma recepção 
determinada. Porém, através do que o autor chama de 'jogo entre performativos', ou seja, entre o que é mostrado e o que é sugerido pela imagem, o filme prepara a recepção envolvendo o espectador na trama vivida pelos personagens. $O$ espectador não é obrigado a assumir imediatamente uma posição face ao enredo, mas, pouco a pouco, ele é levado a se identificar com certos personagens e a rejeitar outros.

Servindo como mediação às imagens do desafio de Coirana e do duelo entre este e Antonio das Mortes, o desafio de cordel modifica a postura do espectador perante o espetáculo cinematográfico da violência. No Dragão a violência não diz respeito, como no western, a um ou outro personagem, mas ao estranhamento causado no espectador pelo tipo de composição que o filme propõe. Negando os princípios da arte burguesa voltada para a identificação do público com o destino do herói (representante, por sua vez, dos valores da sociedade burguesa), o cinema de Glauber Rocha, por meio das estruturas narrativas do cordel, aposta em um novo tipo de recepção: uma recepção que favorece a atitude critica do espectador face às imagens.

A relação intertextual do cordel nos dois filmes analisados se processa no nível de suas respectivas estruturas de comunicação. E é isso que os distingue tanto dos filmes interessados em retratar o sertão, sua realidade política e social, quanto dos que se voltam para as suas tradições. O que está em jogo no cinema de Glauber Rocha é a ruptura com a razão dominante baseada em um modo de representação que se convencionou chamar de 226 clássico. Em contrapartida, o cineasta propõe uma forma de representação construida segundo a lógica dos rituais tradicionais onde prevalecem as idéias de recomeço, de combate, de luta por um mundo melhor, sintetizadas nas imagens do beato e do cangaceiro, do delírio místico e do duelo. Esse sentimento, presente nas expressões da cultura popular, de que é necessário recomeçar sempre, acionar permanentemente o mito como potência transformadora, é que diferencia o trabalho de Glauber Rocha do discurso revolucionário tradicional.

Fundada na esperança, no desejo eterno de transformação, a revolução, para ele, significa luta e, como o mito evocado no cordel de José Pacheco (cantado na íntegra nas últimas sequências de $O$ dragão da maldade), continua vagando indefinidamente através das histórias contadas por nossos poetas (cineastas ou cantadores):

Vou terminar essa história / tratando de Lampião / muito embora que não posso / vos dar a resolução: / no inferno não ficou, / no céu também não chegou / por certo está no sertão. 


\section{As imagens do sertão: 1964 e 1969}

É importante não esquecermos que $O$ dragão da maldade costuma ser pensado como uma continuação de Deus e o diabo. Não se trata de uma avaliação equivocada, mas de uma posição que deve ser problematizada levando em conta que, nesse segundo filme "de aventuras sertanejas" o cineasta não apenas retomou as questões apresentadas anteriormente; ele as retomou transformando-as, reinventando não só a tradição do cordel mas a tradição de representação do sertão no cinema e, para além disso, a sua própria tradição cinematográfica.

Representando um marco entre o antes e o depois no conjunto da obra do cineasta, $O$ dragão da maldade, como certos folhetos de cunho moralista, trata da metamorfose de Antonio das Mortes que, de representante do mal, passa à condição de santo guerreiro. Porém não se trata apenas disso, pois a metamorfose de Antonio das Mortes será acompanhada pela metamorfose do próprio filme que vai se distanciar de seu foco inicial, voltado para a representação das performances populares (como o desafio de cordel e os cortejos de cangaceiros e beatos), para transformar-se a si mesmo em uma performance, em um ato de criação coletiva, como assinalou o cineasta em entrevista ao Cahiers du Cinéma:

Nesse filme eu consegui fazer uma coisa que eu não pude fazer nos outros filmes por conta de problemas de produção. Os atores foram confinados na cidade. Eles não tinham texto para ler, mas nós conversávamos, e foi um trabalho muito natural. De fato, os atores deviam se desembaraçar de sua educação. Eu filmei alguns planos com atores que se encontravam atrás da câmera e que podiam entrar em ação a qualquer momento. Além disso, nada estava previsto, mas já estava inscrito no clima que se instaloti. Foi por isso que eu filmei os planos em ordem: o segundo depois do primeiro etc. Mesmo não havendo continuidade, nós podíamos retomar no final do clima. Nós filmamos apenas uma tomada de cada vez, não havia possibilidade de repetição já que a sequêencia nascia de um certo estado dos atores. Não foi algo previsto. Eu achei mesmo que isto ultrapassou um pouco o clima geral do filme, mas depois, durante a montagem... ${ }^{8}$

Realizado em 1969, época em que a televisão, já implantada em quase todo o território nacional, transformava o país numa aldeia global, $O$ dragão da maldade é um filme que remete ao ato de representação, ao papel da imagem na sociedade. Godard, nome central nesse tipo de reflexão, foi uma influência importante no período para Glauber que inclusive participou de uma cena de Vento do leste (1969), filme do cineasta francês onde ele aparece de pé com os braços estendidos em uma encruzilhada de três estradas, indicando o caminho do cinema político. A fala de Glauber em Vento do leste 
(citada em $O$ último escândalo de Godard ${ }^{\text {D }}$ ) retoma algumas questões apresentadas em $O$ dragão da maldade. Colocando em discussão a posição de Godard em relação à idéia de destruição do cinema, essa fala indica, além da rejeição de Glauber a tal posicionamento, um possível caminho para o cinema do Terceiro Mundo.

Voltados a uma crítica radical ao mundo das imagens, os filmes de Godard eram, na verdade, colagens, composições feitas a partir de fragmentos de outros filmes, notícias, músicas, cartazes etc. $O$ dragão da maldade recorre a um procedimento semelhante utilizando referências internas ao campo cinematográfico, como é o caso do western, e externas, como o desafio de cordel. Mas não se trata aqui, exatamente, de discutir, como nos filmes de Godard, a questão da imagem e sim o problema, mais geral, da representação. Isso fica claro, por exemplo, nas cenas de combate que misturam referências dos duelos do western com os desafios repentistas. As duas manifestações, tal como apresentadas no filme, ou seja, fora de seu contexto original e associadas uma a outra por meio do diálogo que entre elas se estabelece, provocam no espectador um efeito de estranhamento, um distanciamento em relação ao modelo de representação dominante no cinema comercial.

No que se refere à desconstrução de um certo modo de fazer cinema, é muito claro o vínculo entre Glauber e Godard. Porém, a questão que interessava a Glauber era outra, assim como outra a realidade em que vivia o cineasta. Negando a idéia de destruir o cinema, Glauber dizia: 'É preciso 228 continuar a fazer cinema no Brasil!" ' . Não se trata, portanto, de simplesmente 'destruir o cinema', mas de uma destruição acompanhada de um processo de reconstrução.

A citação da poesia popular sertaneja se inscreve nessa proposta de realizar, por intermédio do procedimento intertextual, um novo tipo de criação cinematográfica. Na verdade isso não é uma novidade na cinematografia de Glauber Rocha: em Deus e o diabo o cineasta já fazia uso do cordel para criar um contraponto narrativo às imagens; em Terra em transe é a poesia de Mário Faustino que faz esse papel. Porém, em $O$ dragão da maldade o uso da citação não apenas serve para criar um contraponto entre a narração e a imagem, mas principalmente para promover uma inversão no sentido original da imagem que assume, assim, sua condição de espetáculo, de performance. Inclusive, o uso da citação em off, predominante em Deus e o diabo, não é comum nesse filme que adota, preferencialmente, a fala declamada, mecanismo que aprofunda ainda mais a idéia de artificio da representação.

Deve-se lembrar que, na época da realização do filme, várias experiências teatrais estavam se desenvolvendo e que havia da parte de Glauber um interesse muito grande em relação d̀s manifestaçðes de vanguarda. Na já citada entrevista ao Cahiers du Cinéma ${ }^{\prime \prime}$, ele comenta sobre a montagem de $O$ rei da vela de José Celso Martinez. 
No Brasil há um diretor chamado Martinez que montou uma peça a partir de Oswald de Andrade, $O$ rei da vela. Ele estudou o teatro de boulevard, esqueceu Brecht e a peça é fantástica, muito brechtiana. Ele encontrou tudo ao se livrar de todo brechtismo e fez, no entanto, um espetáculo surpreendente, fantástico. ${ }^{12}$

O problema que Glauber coloca é o das influências que, em vez de enriquecerem a obra, acabavam muitas vezes funcionando como uma camisade-força. Não é esse, contudo, o caso de Martinez cujo encontro com Brecht se deu, como observou Glauber, por meio do teatro de boulevard. O mesmo pode ser dito em relação ao cineasta para quem a influência de Brecht, assim como a de Godard, passava pela mediação das formas populares, da música, das danças etc. O que, no entanto, é importante reter é a nota de esperança que Brecht, ao contrário de Godard, ajudava a introduzir na obra. $\mathrm{E}$ isso, nos paises do chamado Terceiro Mundo, tinha de fato um peso ${ }^{13}$. No Brasil, no entanto, o momento era extremamente dificil e Glauber, artista profundamente ligado às questões do seu tempo, não podia manter-se imune ao sentimento de desesperança que, então, se abateu sobre as cabeças pensantes do país.

Mistura insólita de ironia, didatismo e delírio, $O$ dragão da maldade expressa muito bem as tensões de Glauber quanto a se manter fiel aos ideais de transformação social propagados pelo Cinema Novo ou seguir outro caminho (adotando, por exemplo, a linha do Cinema Marginal voltado para um discurso completamente sarcástico e demolidor). Em suas cartas, o cineasta manifesta sua dificuldade em adotar uma posição: o Cinema Novo, segundo ele, estava esgotado; o Cinema Marginal ele desconsiderava ${ }^{14}$. Não há, contudo, nessa recusa de Glauber em aceitar o Cinema Marginal's, qualquer sinal de nostalgia em relação às formas de cinema político do passado. $\mathrm{Na}$ verdade, se há um traço que nele se destaca é a ligação intensa com o momento vivido e a necessidade constante de reinventar o seu cinema, como se vê inclusive em $O$ dragão da maldade onde sua volta ao sertão se faz acompanhar da necessidade de discutir novas questões, introduzir uma nota de diferença àquele sertão fechado de Deus e o diabo. Nesse sentido, o sertão de 1969, paralelamente ao que fazia um dos principais movimentos de vanguarda da época (o Tropicalismo, que juntava 'margarina' e 'Amaralina', 'bossa' e 'palhoça'), está repleto de elementos da cultura urbano-industrial: o posto de gasolina, os veículos, o rádio, as músicas (Carinhoso e Cheiro de Carolina), as latas vazias servindo como vasos de planta e os próprios personagens de Laura, Matos e o professor que fazem penetrar no sertão não apenas os figurinos mas também a moral da cidade grande.

O filme, em sua profusão de sentidos, expressa, na verdade, uma ausência de sentido. Marcado pelo enrijecimento da ditadura, pelo fim das utopias e dos ideais revolucionários, pela presença, considerada alienante, da televisão no cotidiano da sociedade brasileira, pelo surgimento dos 
movimentos de contracultura, $O$ dragão da maldade é fruto de um momento histórico distinto do de Deus e o diabo. Apesar de apenas cinco anos separarem a realização dos dois filmes, esses foram anos de intensas mudanças sociais, culturais, ideológicas, em suma, de uma profunda mudança de mentalidade. O que não significa que o sertão tenha mudado nesse período; o que efetivamente mudou foi a forma de olhá-lo.

Até 1964 ainda era predominante a crença na possibilidade de se mudar o país, ou melhor, de se mudar o mundo. Deus e o diabo, como basicamente toda a arte política então produzida, se inscreve nesse contexto ideológico cuja referência é a arte como agente da revolução. Bastante homogêneo em suas referências, o filme de 1964, ao contrário de $O$ dragão da maldade onde a busca carece inteiramente de sentido ${ }^{16}$, trata de uma busca concreta, ainda que tal concretização se dê mais no plano da idéia, da imaginação, do que da realidade (já que a revolução, como objetivo dessa busca, permanece, no final, em aberto).

Em Deus eo diabo as canções estabelecem uma ligação entre o início, o meio e o fim da história, ajudando a construir o sentido dessa história no qual o final já estava, de certa forma, previsto no começo. Característico do discurso profético, esse modo de contar a história assume, em Deus e o diabo, uma versão politizada que mesmo diferente da pregação do beato Sebastião (personagem que representa o messianismo stricto sensu), não deixa de estar, de certa forma, a ela relacionada. Resumindo: a idéia de revolução é atravessada pelo ideal profético, sintetizado, no filme, pela imagem da busca utópica da salvação. Embora secularizada, essa interpretação teleológica do "sentido da história", segundo palavras de Karl Lowith", era comum entre segmentos da esquerda nas décadas de 1950 e 1960 voltados para os movimentos de libertação nacional no Terceiro Mundo. Nesses movimentos, o sentimento de revolta contra as injustiças representou muito mais em termos de mobilização das massas (nos paises onde tais movimentos ocorreram) do que a racionalidade do partido comunista.

Os deserdados da Terra, escrito por um psicologo caribenho que tomou parte da guerra de libertação da Argélia, tornou-se um texto de enorme influência entre ativistas intelectuais, que ficaram emocionados com seu elogio da violência como uma forma de libertação espiritual para os oprimidos. ${ }^{18}$

Coerente com o ambiente cultural da época de sua realização, Deus e o diabo, na sua forma de pensar o tempo, a história e a revolução, reafirmava a crença na existência de um processo que caminhava inevitavelmente para sua futura realização.

No final da década de 1960, com a renovação do marxismo, com o interesse por autores como Marcuse, Walter Benjamin e Althusser, por 
exemplo, começou a se manifestar, entre intelectuais e artistas, uma forma menos determinista de pensar o mundo e a revolução. Recusando a política tradicional, o predomínio do Estado, do partido, da burocracia, enfim, a fusão do indivíduo na totalidade, surge como lema a verdade triunfante dos desejos, a rebeldia, a contestação, a crítica ao establishment. Característico desse momento, o slogan do movimento de Maio de 68 , 'sejamos realistas, exijamos o impossivel', espalhou-se rapidamente da França para outros países: Itália, Alemanha, Inglaterra, Tchecoslováquia etc ${ }^{19}$. No Brasil o ano de 1968 foi de grande agitação politica e cultural. Em vários estados organizaram-se movimentos estudantis, passeatas de protesto e greves operárias. A contestação, que também explodiu no teatro e na música, foi acompanhada por violentos atos de repressão. As filmagens de $O$ dragão da maldade foram feitas em meio a esse clima de rebeldia generalizada, por um lado, e de radicalização da ditadura, por outro.

Uma das preocupações de Glauber, naquele momento, era fazer o seu filme chegar ao público. Desde Terra em transe já se percebia a inquietação do cineasta com a distância existente entre o intelectual e o povo. Mas apesar de tematizar a questão, o filme era dirigido a um público de iniciados, como, aliás, toda a produção do Cinema Novo. E essa era inegavelmente a grande contradição do movimento cujos filmes falavam do povo, mas não chegavam ao povo; um dos obstáculos era a distribuição, o outro, a linguagem utilizada pelos cineastas. Glauber comenta sobre sua intenção de realizar com $O$ dragão da maldade um cinema popular:

Fiz Antonio das Mortes ( $O$ dragão da maldade contra o santo guerreiro) procurando simplificar para o 'grande público' uma série de problemas complexos, que lhes oferecia nos termos mais simples possiveis; apresentar um panorama mais aberto, espontâneo, sem romantismos, suprimindo os personagens intelectuais dos meus outros filmes. ${ }^{20}$

Considerando que nessa época a televisão brasileira começava a se expandir, a preocupação que Glauber manifesta com o 'grande público' parece demonstrar o seu interesse pelo meio ${ }^{21}$. E, de fato, apesar das críticas do cineasta à submissão da televisão brasileira ao que ele costumava chamar de modelo colonizador, havia de sua parte um grande interesse em produzir filmes para a TV ${ }^{22}$. O problema é que a partir de meados dos anos 1960 a hegemonia da Rede Globo passou a dificultar a realização de qualquer projeto no âmbito da televisão brasileira que não estivesse enquadrado no modelo de Brasil concebido pela ditadura militar. Além disso, 'o 'padrão Globo de qualidade', exemplo de modernização capitalista, não seria incompativel com a estética da fome, esta estética da violência e do subdesenvolvimento brandida ferozmente por Glauber Rocha e o Cinema Novo? ${ }^{23}$ 
Com a criação da Rede Globo, a televisão transformou-se repentinamente em principal veículo de massa e divertimento popular. Essa situação, que representou para a população brasileira uma profunda revolução de costumes, fez crescer, entre artistas e formadores de opinião, um movimento de crítica aos produtos midiáticos e à chamada massificação cultural. Para os jovens realizadores a crítica aos 'enlatados', à alienação, se dava em um tom de ironia, às vezes debochada, mas para os cineastas comprometidos com 0 Cinema Novo a percepção da imobilidade do povo, ou melhor, da incapacidade deste se mobilizar (principalmente no sentido de evitar o golpe militar), foi motivo de desencanto, frustração e, num certo sentido, os desviou do rumo inicialmente adotado.

Assim sendo, e ao mesmo tempo em que o cenário dos filmes se deslocará predominantemente do campo para a cidade, significando talvez o abandono da crença de que a revolução começaria no campo, os personagens centrais passam a ser o poeta de Terra em transe (1967), de Glauber, os jornalistas de $O$ desafio (1965), de Paulo Cesar Saraceni,...24

Nesse clima de perplexidade, Glauber Rocha (que em 1966, com Terra em transe, havia manifestado sua decepção em relação à ausência de ação do povo) lança em 1969 O dragão da maldade contra o santo guerreiro estabelecendo um novo ponto de vista acerca da noção de participação popular. Comentando sobre a população de Milagres e sua participação no filme, Glauber Rocha, na entrevista dada ao Cahiers du Cinéma ${ }^{25}$, deixa claro que, naquela situação, o que estava em jogo em relação ao povo eram os seus cantos, suas danças, suas expressões que constituíam a força viva do espetáculo. Em outro texto Glauber explicita sua opção pelas manifestações populares:

A cultura popular, no caso, a poesia de cordel, que articulava a narrativa de Deus e o diabo, se inscrevia em um universo relativamente fechado de experiências. $O$ filme conta a história de Manuel e Rosa; uma história ocorrida no passado (Manuel e Rosa viviam no sertão...), mas que se repete no presente. A canção final dá a moral da história indicando que o homem pode transformar o seu destino (Tá contada minha história, verdade e imaginação, espero que senhor tenha tirado uma lição, que assim mal dividido esse mundo anda errado, que a terra é do homem, não é de Deus nem do diabo.).

A idéia de que o futuro da sociedade depende da ação coletiva, distancia Deus e o diabo da poesia de cordel (onde a mudança se circunscreve à experiência individual) e o inscreve em sua própria historicidade. Na época da realização do filme os principais projetos culturais ${ }^{26}$ se desenvolviam nos meios rurais e tinham como meta a conscientização do camponês tendo em vista a Reforma Agrária. 
O dragão da maldade se inscreve em um contexto distinto no qual a experiência não é mais transmitida, ela é a própria razão de ser da obra. Não é à toa a vinculação do filme a uma expressão poética onde a criação é simultânea à transmissão e a participação do público vital na evolução do espetáculo. Ao contrário do folheto, cuja narração remete a algo ocorrido no passado, o desafio repentista é uma poesia do presente, do instante, do improviso. Em um caso, trata-se de contar uma história. No outro, de provocar uma experiência:

não mais narrar uma estória, transmitir uma determinada experiência existencial, pessoal ou histórica, para cujo fim o filme não passaria de mero suporte, de simples veiculo. Mas sim considerar o cinema como essa própria experiência/vivência. Conceber o filme não como o meio para emitir conceitos e conteúdos, mas como o espaço para a experimentação de processos novos... ${ }^{27}$

A opção pelo experimentalismo faz parte do contexto da contracultura que envolveu as mais diferentes manifestações culturais. Em comum entre elas havia a idéia de que o público ajudava a fazer o espetáculo: os happenings de arte plásticas, os Festivais da Canção, o Teatro de Arena, o Oficina, os shows do Opinião e, acima de tudo, as passeatas de protesto que reuniam nas ruas milhares de pessoas em atitude de contestação à ordem ${ }^{28}$. Essa insubordinação generalizada, essa rebeldia, essa energia espontânea que brotava nos palcos e nas ruas difere completamente da noção de participação do inicio dos anos 1960 quando o fazer político estava atrelado aos partidos, sindicatos e organizações de classe.

Nesse ambiente, onde a arte era uma militância, a massa estava absorvida na mensagem do seu líder. Esse é o retrato mostrado no filme de $1964 \mathrm{em}$ que a câmera fixa, à maneira do cinema político da época ${ }^{29}$, denuncia a imobilidade da população sertaneja, a sua incapacidade para a ação. Totalmente diferentes são as imagens do filme de 1969 onde o povo, repetindo velhos rituais, não apenas participa como faz acontecer o espetáculo.

A própria idéia de espetáculo merece ser reconsiderada pois, nesse filme, o que está em jogo, no que se refere à apropriação das tradições populares, é a carnavalização do mundo da ordem e seus espetáculos tradicionais: a parada de Sete de Setembro, por um lado, e, por outro, o espetáculo cinematográfico, o cinema de aventura, de violência, normalmente fundado sobre uma perspectiva de arte burguesa. O filme também carnavaliza a noção de popular como folclore desenvolvida por intelectuais da cultura que se dirigiam ao povo com um olhar de especialista.

Em seu aspecto livre, lúdico e desordenado as manifestaçðes da cultura popular, tais como apresentadas em $O$ dragão da maldade, invertem a rigidez e os códigos da cultura oficial e da arte burguesa estabelecendo um 
contraponto à sua hegemonia. Ao contrário de Deus e o diabo, voltado para a narração, para a repetição da história, aqui o que interessa é a sua teatralização, a sua carnavalização.

Outro ponto que deve ser considerado, quando se trata das diferenças entre o filme de 1964 e o de 1969, é a introdução do som direto ${ }^{30}$ e do equipamento leve que permitiu a $O$ dragão da maldade registrar, à maneira das reportagens televisivas ${ }^{31}$, os cantos improvisados dos dos habitantes da Vila de Milagres. Deve-se, portanto, levar em conta, quando se observa a forma do povo ser representado em cada um dos filmes, por um lado, as mudanças ideológicas, que repercutiram no modo do artista dirigir seu olhar às manifestações populares, e, por outro, as mudanças tecnológicas, que deram nova configuração a tais manifestações. Extremamente atento ao que ocorria à sua volta, Glauber Rocha, em suas duas visões do sertão, revela algumas das principais mudanças ocorridas no país naquele periodo em que tudo desabava e tudo ainda parecia possível.

\section{Referências bibliográficas}

BENJAMIN, Walter. "O Narrador" in Obras Escolhidas I. São Paulo, Brasiliense, 1993.

BENTES, Ivana. Cartas ao mundo. São Paulo, Companhia das Letras, 1997. BERNARDET, Jean-Claude. Cineastas e imagens do povo. São Paulo,

234 Companhia das Letras, 2003.

BORGES, Luiz Carlos. O cinema à margem: 1960-1980. Campinas, Papirus, 1983.

DAYAN, Daniel. "Lê spectateur performé" in Hors Cadre 2-Cinénarrable. Vincennes-St.Dennis: Presses et publications de l'Université Paris VIII, 1984. DELAHAYE, Michel, KAST, Pierre, NARBONI, Jean. "Entretien avec Glauber Rocha" in Cahiers du Cinéma, n. 214, jul/ag., 1969.

FERREIRA, Jerusa Pires. Cavalaria em cordel -o Passo das Águas Mortas. São Paulo, Hucitec, 1979.

GUATHIER, Guy. Chris Marker, écrivain multimedia ou Voyage à travers les medias. Paris, L'Harmattan, 2001.

HOBSBAWN, Eric. Era dos extremos: O breve século XX-1914-1991. São Paulo, Companhia das Letras, 1995.

HOLANDA, Heloisa B. de, GONÇALVES, Marcos A. Cultura e participação nos anos 60. São Paulo, Brasiliense, 1990.

ISHAGHPOUR, Youssef. D'une image a l'autre - La representation dans le cinema d'aujourd'hui. Paris, Denoel/Gonthier, 1982.

LOWITH, Karl. O sentido da história. Rio de Janeiro, Edições 70, 1981. MATOS, Olgária C. F. Paris 1968: as barricadas do desejo. São Paulo, Brasiliense, 1989. 
PARANAGUÁ, Paulo Antonio. "Le cinéma face au défi de la television" in Paulo Antonio Paranaguá (org). Le cinéma brésilien. Paris, Centre Georges Pompidou, 1987.

RICOEUR, Paul. Tempo e narrativa III. Campinas, Papirus, 1997.

ROCHA, Glauber. Revolução do Cinema Novo. Rio de Janeiro, Alhambra/ Embrafilme, 1981.

O século do cinema. Rio de Janeiro, Alhambra/Embrafilme, 1985.

VALENTINETTi, Cláudio M. Glauber Rocha: um olhar europeu. São Paulo, Instituto Lina Bo e Pietro M. Bardi, Prefeitura do Rio, 2004.

WARREN, Paul. "La voix off dans Sunset Boulevard" in Cinémas - Révue d'études cinématographiques. Cinélekta, printemps, 1995.

\section{Notas}

2 Jerusa Pires Ferreira. Cavalaria em cordel-o Passo das Águas Mortas. São Paulo: Hucitec, 1979.

${ }^{3}$ Glauber Rocha. Revolução do Cinema Novo. Rio de Janeiro: Alhambra/Embrafilme, 1981.

"Paul Warren. "La voix off dans Sunset Boulevard" in Cinémas - Révue d'études cinématographiques. Cinélekta, printemps 1995.

"Walter Benjamin. "O Narrador" in Obras Escolhidas I. São Paulo: Brasiliense, 1993.

' Paul Ricoeur. Tempo e narrativa III. Campinas: Papirus, 1997, p 327.

'Daniel Dayan. "Le spectateur performe" in Hors Cadre-2 - Cinénarrable-2.

Vincennes-St.Dennis: Presses et publications de l'Université Paris VIII, 1984.

"Michel Delahaye, Pierre Kast e Jean Narboni. "Entretien avec Glauber Rocha" in Cahiers du Cinéma, n. 214, jul/ag. 1969.

${ }^{9}$ Glauber Rocha. O século do cinema. Rio de Janeiro, Alnambra/Embrafilme, 1985, p. 241.

${ }^{10} /$ bid., p. 242.

${ }^{10}$ Michel Delahaye, Pierre Kast e Jean Narboni. Op.cit.

12 Ibid., p. 29.

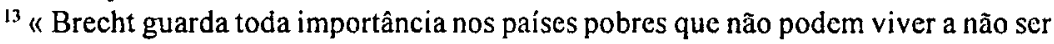
de esperança. E são muitos os filmes militantes que continuam no mesmo caminho » (trad. S.R.B.N.) in Youssef Ishaghpour. D'une image a l'autre - La représentation dans le cinéma d'aujourd 'hui. Paris, Denoel/Gonthier, 1982, p 78.

${ }^{14}$ Em uma dessas cartas (enviada de Santiago em maio de 1971 para Alfredo Guevara), Glauber comenta sobre a situação do cinema brasileiro após o golpc de 1964 fazendo um balanço do Cinema Novo e uma crítica à chamada 'segunda geraçăo' in Ivana Bentes. Cartas ao mundo. São Paulo, Companhia das Letras, 1997, p 400-412.

${ }^{15}$ A posição de Glauber contraria a proposta do Cinema Marginal que rompeu com o tom engajado do Cinema Novo mas nao representou uma ruptura em relação deste como observou Luiz Carlos Borges. O cinema à margem : 1960-1980. Campinas, Papirus, 1983, p 43-44. 
${ }^{16}$ No final do filme Antonio das Mortes caminha sem rumo entre caminhões por uma auto-estrada; o professor permance parado diante da igreja agarrado ao corpo de Laura ; o padre, a Santa e o Negro Antão aparecem pela última vez estáticos na cena do combate da qual ensaiam uma retirada. Qual, portanto, o destino dos sobreviventes da batalha entre o Dragão e o Santo Guerreiro ?

${ }^{17}$ « ... a história secreta do Manifesto Comunista não é o seu materialismo consciente e a opinião pessoal de Marx a seu respeito, mas o espírito religioso do profetismo. " in Karl Lowith. O sentido da história. Rio de Janeiro, Edições 70, p 51 . Nesse livro o autor deixa claro, tomando como referência determinada linha historiográfica, que " sentido » não não se refere apenas a significado mas também a direção.

${ }^{18}$ Eric Hobsbawn. Era dos extremos : O breve século XX-1914-1991. São Paulo, Companhia das Letras, 1995, p 430.

${ }^{19}$ Sobre o movimento de 'Maio de 68' ver Olgaria C. F. Matos. Paris 1968: as barricadas do desejo. São Paulo, Brasiliense, 1989.

${ }^{20}$ Cláudio M. Valentinetti. Glauber Rocha : um olhar europeu. São Paulo, Insitituto Lina Bo e Pietro M. Bardi, Prefeitura do Rio, p 96.

${ }^{21}$ Mais tarde, em 1979, Glauber participará do programa Abertura na extinta TV Tupi no qual ele « destrói sistematicamente todas as normas do bom gosto televisivo " (trad. S.R.B.N.) Paulo Antonio Paranaguá. « Le cinéma face au défi de la television 》 in Paulo Antonio Paranaguá (org). Le cinéma brésilien. Paris, Centre Georges Pompidou, 1987, p 248.

${ }^{22}$ Comentário de Glauber Rocha em Op.cit. 1981, citado em ibid., p 245.

${ }^{23}$ Paulo Antonio Paranaguá. Op.cit., p 245 (trad. S.R.B.N.)

${ }^{24}$ Luiz Carlos Borges. Op.cit., p 39.

${ }^{25}$ Ver nota 8

$236{ }^{26}$ Entre os principais projetos culturais do período destacam-se o Movimento de Educação de Base orientado pelo método de alfabetização de Paulo Freire e os CPCs (Centros Populares de Cultura).

${ }^{27}$ Luiz Carlos Borges. Op.cit, p 48-49.

${ }^{28}$ Sobre os movimentos de contracultura ver Heloisa B. de Hollanda e Marcos A Gonçalves. Cultura e participação nos anos 60. São Paulo, Brasiliense, 1990.

${ }^{29}$ Em Vidas secas de Nelson Pereira dos Santos e Os fuzis de Ruy Guerra, realizados na mesma época que Deus e o diabo, observa-se o mesmo tratamento da imagem do povo.

${ }^{30} \mathrm{~A}$ respeito do som direto em $O$ dragão da maldade ver comentário de Glauber em Michel Delahaye, Pierre Kast e Jean Narboni. Op.cit., p 34. Também em Cláudio M. Valentinetti. Op. Cit., p 145-150 há referências às experiências de Glauber Rocha com

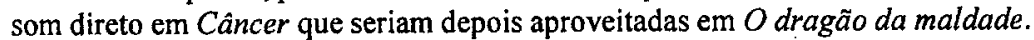

${ }^{31} \mathrm{O}$ cinema de Eduardo Coutinho, na fala dos entrevistados, se vale dessa mesma instataneidade que marcou as filmagens de $O$ dragão da maldade. Coutinho, que trabalhou no programa Globo Repórter, concluiu em 1984 o filme Cabra marcado para morrer, iniciado em 1962 e interrompido pelo golpe militar em 1964. Vale resśaltar que a segunda versão do filme traz a marca da experiência de Coutinho com as reportagens televisivas (ver Jean-Claude Bernardet. Cineastas e imagens do povo. São Paulo, Companhia das Letras, 2003, p 233). A diferença entre Glauber e Coutinho corresponde, em linhas gerais, a diferença dos estilos de Chris Marker e de Jean Rouch no cinema verdade. Para uma comparação entre os estilos de Chris Marker e Jean Rouch ver Guy Guathier. Chris Marker, écirvain multimédia ou Voyage à travers les médias. Paris, L'Harmattan, 2001. 


\section{NORMAS PARA PUBLICAÇÃO}

\section{Submissão de artigos}

Contracampo acolhe colaborações de autores do Brasil e do exterior, pertencentes ou não a programas de Comunicação. Os trabalhos submetidos são avaliados por dois pareceristas do Conselho Editorial e publicados após recomendação de ambos, obedecendo às datas de fechamento dos números semestrais.

\section{SOMENTE ARTIGOS INÉDITOS PODERÃO SER SUBMETIDOS À CONTRACAMPO.}

\section{Formato e preparação de artigos para submissão}

Os trabalhos submetidos devem possuir entre 5000 a 7000 palavras, ou de 13 a 15 laudas, digitadas em Word (ou similar), fonte Times New Roman, corpo 12.

O formato da página adotado para os trabalhos é o $\mathrm{A} 4(21 \times 29.7 \mathrm{~cm})$ com as seguintes medidas: $2 \mathrm{~cm}$ de margem superior; $3 \mathrm{~cm}$ de margem inferior, $5 \mathrm{~cm}$ de margem esquerda, $3 \mathrm{~cm}$ de margem direita e medianiz 0 . Cabeçalho de $1,2 \mathrm{~cm}$ e rodapé de $1,6 \mathrm{~cm}$. Alinhamento pela esquerda somente.

O espaço entre linhas deve ser simples para o corpo do texto, e o espacejamento do parágrafo deve ser de 12 antes e 6 pontos depois de cada parágrafo, com recuo direito e esquerdo de valor 0 .

Todos os parágrafos devem ser indentados em $0.5 \mathrm{~cm}$.

\section{Título e autoria}

Fonte Arial, negrito, corpo 12, centrado e espacejamento entre linhas de 1,5 linhas. Usar caixa-alta (letra maiúscula) apenas para a primeira letra do título do artigo, exceto para nomes próprios ou palavras que exijam o uso de caixa-alta por razões gramaticais.

O nome do autor deve ser colocado abaixo da última linha do título, centrado, em Arial, itálico, corpo 10. Se o artigo possuir mais de um autor, separar os nomes destes com um vírgula e espaço. Se o número de autores xceder uma linha, não dividir o nome de um autor: coloque-o na linha seguinte. O nome 
de cada autor deve estar na seguinte ordem: primeiro nome, segundo nome ou inicial (se for o caso) e o sobrenome.

Incluir no final da primeira página do artigo nota de rodapé (com entrada após o sobrenome de cada autor, numeração personalizada por asterisco) com dados biográficos sobre o(s) autor(es), constante de filiação institucional, titulação etc. com cerca de 50 palavras, em fonte Arial, regular, corpo 9.

\section{Palavras-chave e resumos}

As palavras-chaves e resumo em português devem vir após o título e nome dos autores.

Usar 3 a 5 palavras-chaves, fonte Arial, corpo 10. Estas devem ser colocadas antes do resumo e serem antecedidas da palavra: "Palavras-chaves", alinhada à esquerda, em Arial, negrito, corpo 10.

O resumo deve ter aproximadamente 150 palavras. Usar fonte Arial, corpo 10 para o resumo. As especificações para parágrafo e coluna são as mesmas do corpo do texto (siga as instruções dadas para margens, espacejamento, indentação, coluna e alinhamento). O resumo deve ter como título a palavra "Resumo", alinhada à esquerda, em Arial negrito, corpo 10. Na linha seguinte 238 coloque o texto do resumo.

As palavras-chaves e resumo em inglês devem observar o mesmo formato para o português, sendo, porém, em itálico. Devem vir após o resumo em português. Substituir os títulos: "Palavras-chaves" por "Keywords" e "Resumo" por "Abstract", para as palavras-chaves e resumo em inglês.

O texto do artigo deve ser iniciado na página seguinte às palavras-chaves (keywords) e ao resumo (abstract) em inglês. Para tanto, inserir quebra de página entre a página com título, autoria, resumo e abstract e corpo do artigo. Não inserir numeração nas páginas.

\section{Subtitulos}

Sugerimos o uso de não mais de três níveis de subtitulos para seu artigo, os quais devem seguir estas especificações:

primeiro nivel de subtítulo: Arial, negrito, corpo 11, alinhado à esquerda, espaço de parágrafo de 24 pontos antes do subtítulo e de 6 pontos após o subtítulo; 
- segundo nível de subtítulo: Arial, negrito, corpo 10 , indentado em $0.5 \mathrm{~cm}$, espaço de parágrafo de 12 pontos antes do subtitulo e de 6 pontos após o subtítulo;

terceiro nível de subtítulo: Arial, negrito, itálico, corpo 10, indentado em $1.0 \mathrm{~cm}$, espaço de parágrafo de 12 pontos antes do subtítulo e de 6 pontos após o subtítulo.

Usar caixa-alta (letra maiúscula) apenas para a primeira letra do subtitulo do artigo, exceto para nomes próprios ou palavras que exijam o uso de caixa-alta por razões gramaticais.

Inserir um parágrafo (Enter) entre o texto que antecede o subtitulo e este.

\section{Imagens}

Para o envio de material fotográfico, os editores devem ser previamente contatados para maiores especificações.

\section{Citações}

Para citar um autor no corpo do texto use 'aspas simples'. Citações que excedam três linhas devem ser separadas do corpo do texto (aperte a tecla 'enter' uma vez).

Para citações, usar fonte Arial, regular, corpo 9, alinhamento à esquerda. Espacejamento entre linhas deve ser simples, recuo de parágrafo de $0,5 \mathrm{~cm}, \mathrm{e}$ espaço de 6 pontos após cada parágrafo de sua citação (se for o caso).

\section{Notas}

Usar notas de final de documento apenas, com exceção da nota biográfica do(s) autor, que aparece na primeira página do artigo. Usar fonte Arial, regular, corpo 9; e alinhar o texto pela esquerda. Usar notas de rodapé quando absolutamente necessário e evitar notas longas. As notas devem ser numeradas consecutivamente ao longo do texto.

\section{Referências}

As referências bibliográficas devem vir logo após a seção de notas e seguir a NBR 6023 DA ABNT, observado o formato de margens e espaços definidos 
acima. Todas as referências devem vir listadas alfabeticamente e cronologicamente na seção de referências, sob o título "Referências" (ver especificações para títulos de primeiro nível). Para formatar as referências use fonte Times New Roman, regular, corpo 12, alinhamento à esquerda, espacejamento simples entre linhas, recuo especial de $0,5 \mathrm{~cm}$ da segunda linha em diante e espaço de parágrafo de 6 pontos após cada referência.

\section{Considerações sobre direitos autorais}

Os artigos submetidos devem vir acompanhados de autorização de publicação pelo autor.

Contracampo detém o copyright sobre o conteúdo da publicação aceita.

Fotocópias de artigos são autorizadas mediante solicitação aos editores e crédito das fontes.

Para evitar violação das leis de direitos autorais, favor não utilizar longas e muitas citações de uma mesma fonte, ou figuras publicadas previamente sem um documento de autorização de uso dos direitos autorais. Isto também se refere a imagens produzidas pelo autor, publicadas em outro veículo, cujo direito autoral tenha sido transferido à editora referente ao veículo anterior.

240 Autores que não fornecerem documentos de autorização de uso de direitos autorais terão seus artigos devolvidos.

\section{Envio de artigos:}

Os originais deverão ser enviados em três cópias impressas, companhadas de disquete, para o seguinte endereço:

Rua Tiradentes, 148 , Ingá

Niterói CEP: $24270-240$

Rio de Janeiro- $\mathrm{RJ}$

Contracampo - Uma revista financiada pelo programa PROAP/CAPES

e-mail para contato: felipepena@globo.com

Editor-chefe: Prof. Dr. Felipe Pena 
IMPRESSẢO

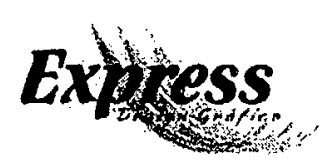

Av. Sen. Vitorino Freire, Od. 35. n 01 - Areinha - Ed Jonas Martins Soares Cep: $65010-650$ - Săo Luis - MA - Tel: (98) 3231-2428/9247 e-mail: expressdesigngráfico@hotmail.com 



\section{Contracampo

\section{Dossiê: Comunicação, Infância e Adolescência}

A pesquisa em jornalismo e as noticias sobre as crianças e adolescentes Cristina Ponte

A infância no noticiário latino-americano: realidades e desafios da pesquisa jornalistica Rosane Rosa

Investigación del trabajo com el diário en el aula de estudiantes y profesores Lucía Castellón e Catalina Mujica

Desafios da pesquisa em comunicação com foco na criança e no adolescente no Brasil Inês Silva Vitorino Sampaio

Apontamentos sobre a relevância da mídia para o contexto amplo da infância, adolescência e juventude Guilherme Canela de Souza Godoi

Entrevista

Luis Erlanger (Diretor da Central Globo de Comunicação)

Felipe Pena

Artigos

Graciliano. Literatura, criação cultural e engajamento

Dênis de Moraes

A identificação nas formas grupais: uma reflexão sob a luz de metáforas cinematográficas Mayra Rodrigues Gomes

A sala dos intervalos no cinema de Fernando Solanas

Miguel Pereira

A História oral como recurso metodológico na entrevista jornalística Marta Regina Maia

Comunicação, sistemas complexos e transdisciplinaridade: um comunicar intercientífico Fátima Régis

Rádio comunitária em Timor-Leste: os meios de comunicação em novos tempos de cidadania Maria Inês Amarante

Comunicacão para educação: uma questão de performance Fernando Álvares Salis

Exclusão e deliberação: buscando ultrapassar as assimetrias do intercâmbio público de razões Rousiley Maia e Ricardo Fabrino Mendonça

Glauber Rocha e as imagens do sertão Sylvia Nemer

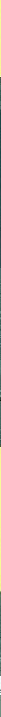

